\title{
Financial Innovation in Tanzania: Opportunities and Challenges
}

\author{
Mohammed Salim Ahmed, Jianguo WEI \\ Wuhan University of Technology, Wuhan 430070, P.R. China
}

\begin{abstract}
Worldwide financial innovations have been explained as among the greater ways of providing various advantages in financial sector. In Tanzania, financial innovation has transformed most traditional and conventional ways of business transaction and international relation between economies. Policy makers had high expectation about the prospect of financial sector which led to significant reforms including financial liberalization and the development of regulatory and supervisory frameworks. The paper review this trend and found that Financial innovation has brought many opportunities including increased menu of financial assets and liabilities to end users, the cost of financial intermediaries have fallen, risk management tools have become increasingly sophisticated and Tanzania have found new ways to mobilize domestic and international savings. However several challenges were discovered as hindering financial innovation including lack of capital, low level of technology, lack of supporting policies and risk creation.
\end{abstract}

KEYWORLD: Financial Sector; Financial Innovations; Challenges; Opportunities.

\section{INTRODUCTION}

In today's fast paced business environment, innovation is a prerequisite for not only success, but also for survival. Innovation is also said to be the most important factor in establishing and maintaining a competitive advantage (Kortum, and Lerner, 2000). The term innovation is defined by Encarta dictionary as the process of inventing or introducing something new (Encarta, 2009). The general definition of innovations explains that they appear when new ideas, solutions and instruments are implemented in order to change the conditions of business entity and to improve its situation (Błach, 2011).

In terms of Financial innovations, there are many definition that has been issued to provide the actual meaning of financial innovations (Bodie and Merton, 2000; Socha, 2003; Rose and Marquis, 2009). The most notably is the definition which was provided by Frame and White which defines financial innovation as something new that reduces costs, reduces risks or provides an improved product/service/instrument that better satisfies participants' demands within a financial system (Frame and White, 2002). Vargas 2008 went further pointing out that when defining financial innovations, the best way is to categorize it into three groups, basing on where innovations occur. Vargas categorizations include: Process innovation which refers to new production processes that allow the provision of new or existing financial products and services; Organizational innovation which encompasses new institutions or organizational structures within institutions where the production process is held; and Product innovations which are new products or services created to meet market needs, thus constituting a client-focused kind of financial innovation.

The financial innovations are not a new phenomenon, as they have been accompanying the technological innovations from the very beginning (Michalopoulos et.al, 2009). Worldwide, the wave of financial innovation begun in the early 1960s is now sweeping throughout the United States and other developed economies (Levich, et al., 1988).

In Tanzania, for the past few years there have been some innovations in financial sector accompanied by elimination of geographical barriers to some financial services, such as money transfer services (Diyamett, 2010). Liberalization of the economy in the country has seen the emergency of both local and international banks into the market, but so far the issue of banking services is still very low to the overall population (BD report, 2010). The financial sector reforms have contributed to the increase in commercial banks' credit to the private sector, growing from about 5.4 percent of GDP in 2001 to about 18.0 percent in 2011 (Wangwe and 
Lwakatare, 2004; Diyamett, 2012). According to the Bank of Tanzania annual reports, the ratio has increased to $21.8 \%$ in December 2013. Currently, there are innovations that are quickly penetrating Tanzania financial market. Such innovations include mobile phone financial services such as Vodacom's M-Pesa, Zantel's Z-Pesa, Airtel Money, TigoPesa; and mobile banking services by financial institutions.

However the rate of financial innovation is still low which in turn affect the overall growth of financial sector. Therefore the paper derived the need to look at comprehensive literature review of financial innovation and provide the status of financial innovation in Tanzania. It also reviews the opportunities and challenges encountered in the process of financial innovation.

\section{METHODOLOGY}

The paper used both primary and secondary sources of information. Theoretical and empirical literatures were reviewed in order to get insight of current situation of financial sector innovation. Primary data was collected using interview with standard set of questions from 150 respondents. The target respondents were customers of the financial institutions mainly banking sector. Observation was also used which enabled author to look at the kind or types of innovativeness that exist.

\section{LITERATURE REVIEW}

Levich et.al. (1988) argue that, the details of the financial innovation process differ country by country, but there are several common features, including: Development of new financial products and market, securitization, liberalization and globalization. The empirical evidence in crosscountry studies has shown, so far, a close relationship between financial intermediation and economic growth. Financial deepening and financial dependence are two key elements in this context. Financial deepening can be defined as the level of development and innovation of traditional and nontraditional financial services. Most of previous studies employed a bank credit variable as a measure of financial deepening (Mackay and Molyneux, 1996).

Financial innovation has come under great criticism since the start of the financial crisis in the summer of 2007 (Allen, 2012). The Global Financial Crisis which occurred between the years 2007 to 2009 has spurred renewed wide-spread debates on the "bright" and "dark" sides of financial innovation (Beck et.al, 2012; Allen, and Yago, 2010). In explaining the outcomes of financial innovations there are two views that are mostly used, these views include the traditional innovation-growth view and the innovation fragility view (Michalopoulos et.al.2009).

The traditional innovation-growth view that financial innovations help reduce agency costs, facilitate risk sharing, complete the market, and ultimately improve allocation efficiency and economic growth, thus focusing on the bright side of financial innovation. While the innovation-fragility view, on the other hand, focuses on the "dark" side and has identified financial innovations as the root cause of the recent Global Financial Crisis, by leading to an unprecedented credit expansion that helped feed the boom and subsequent bust in housing prices (Kortum, and Lerner, 2000; Lerner, and Tufano, 2010).

Despite its crucial importance and the continuing debate, however, there is a striking paucity in the empirical study of financial innovation and its effect on financial fragility and economic development (Fagerberg, and Verpagen, 2004). Hence this paper will utilize the existing gap on the topic to establish the overall status of financial institution in the country through pointing out challenges that hinders the continued improvement of innovations in financial sector.

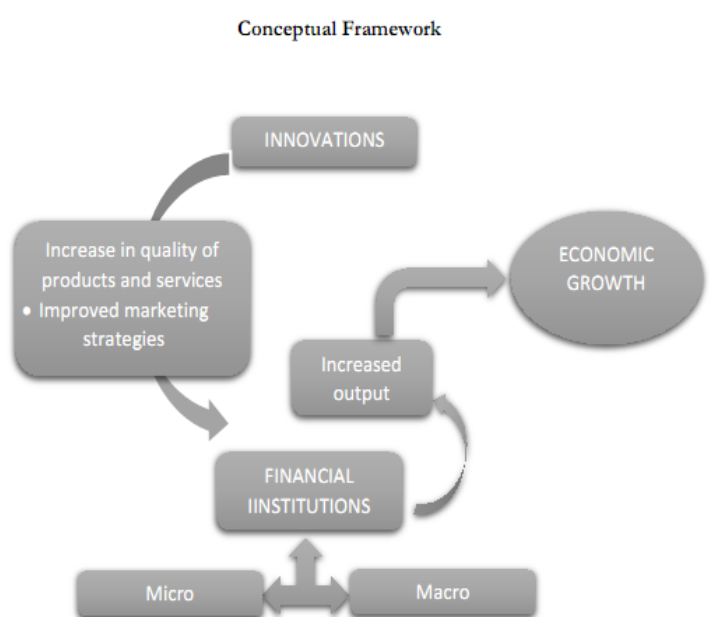

Figure 1 Conceptual framework of financial innovation.

\section{FINANCIAL INNOVATIONS IN TANZANIA}

\subsection{Perception on Innovation status of financial institutions:}

In order to establish the overall status of innovation in Tanzania's financial institutions, the researcher started by establishing the respondents perceptions over this. The question posed to the respondents was simple asking the respondents if there are any significant innovations in the financial institutions. To provide answers for this, the respondents provided simple Yes, No and I don't know answers. The answers for this show that $67 \%$ of the respondents agreed there are financial innovations; 
$28 \%$ of the respondents selected No; and the remaining 5\% said I don't know. Basically, large percentage of the respondents seemed to agree on the existence of financial institutions innovation in the country.

\subsection{Nature of existing financial innovations in the country:}

From there the researcher was interested to establish the nature of innovations that have been made in the country. In this the respondents were given a free option to provide their opinions on the services that have been developed in the country.

The overall results for this shows that, Mobile banking was the one with 46 respondents mentioning this as among the innovations made in the financial sector. This was followed by ATM Cards; in this 41 respondents were under the impression that, the presence of the ATM Cards is one of the innovations that is currently mushrooming in majority of the bank serving to eliminate the customers' long time existence problem of queue. Basically, ATM Cards was sought to be associated with the coming of ATM machines which were all taken as the major improvements in the ATM sectors. After this, another innovation which was mentioned by large percentage of the respondents was Movable banking, in this, 36 respondents mentioned branchless banking as the current existing innovation in the financial sector as several banks are currently having a Van roaming around big cities providing banking services including ATM and customer cares. Other services that were mentioned by small number of the respondents include emoney, personal banking and online banking which all together accounted for 24 respondents. Below table presents these data in a summary form.

Table 1: Respondents opinions on the services developed.

\begin{tabular}{|l|c|c|}
\hline Innovation & Number & $(\mathbf{\% )}$ \\
\hline Mobile Banking & 46 & $31.3 \%$ \\
\hline ATM machine \& Cards & 41 & $28.0 \%$ \\
\hline Movable banking & 36 & $24.4 \%$ \\
\hline Other & 24 & $16.3 \%$ \\
\hline Total & 147 & $100 \%$ \\
\hline
\end{tabular}

\subsection{Customer satisfaction with the current state of financial innovation in a country:}

After establishing the nature of existing financial innovations in the country, the researcher was interested in establishing the customer's satisfaction with the current state of financial innovations within the country. Basically, asking on the respondents to provide their general perception over the rate of satisfaction with state of innovation was used as criteria to see if the respondents are satisfied with the innovations made, or they are still demanding more innovations so as to improve their overall experience in the financial sector. In this, the question posed to the respondent was "How will you rank the current state of financial innovations in your country?". The overall results for this were as follows;

Out of all 150 respondents who were questioned, $36 \%$ selected Excellent as their answer; 28.5\% selected very good as their answer; $10.5 \%$ selected good; $15.5 \%$ selected satisfactory; and the remaining $9.5 \%$ selected poor as their answer. Looking at the answers, one can see that, the number of respondents who have selected excellent and very good $(64.5 \%$ in total) is high compared to those who selected satisfactory and poor (25\% in total). However, despite this big score, the percentage in general is not enough to indicate the level of innovations is of satisfactory stage in the country. Basically, people have experienced various financial innovations outside the country; hence once they come back it is impossible for them to rank the existing state of innovations high. Hence this shows there is a need to continue boosting innovations in the financial sectors so as to improve the overall experience of the customers in the country.

\subsection{The technology development}

Technological changes relating to telecommunication and data processing in Tanzania have motivated financial innovations which have altered financial product and services and production processes. The change was also supported by establishment of new banks including foreign banks, expansion of branch network, growing banks linkage with SACCOS, introduction of agent banking, expansion of mobile banking and integration of mobile financial services to the banking system.

This process has grown significantly overtime and contributed toward wide outreach of financial services to unbanked population of both rural and urban area of the country. There has been a rapid growth in the use of the new financial products over the $2009-2013$ periods as shown in the table 2

Table 2: The use of new financial products.

\begin{tabular}{|l|c|c|c|c|c|}
\hline Category & 2009 & 2010 & 2011 & 2012 & 2013 \\
\hline $\begin{array}{l}\text { Internet banking } \\
\text { (TZS million.) }\end{array}$ & 8,130 & 10,420 & 12,040 & 17,768 & 22,725 \\
\hline $\begin{array}{l}\text { Mobile (SMS) } \\
\text { banking }\end{array}$ & 124 & 155 & 224 & 302 & 587 \\
\hline $\begin{array}{l}\text { Mobile payment } \\
\text { ( O00) }\end{array}$ & 156 & 1,006 & 5,563 & 17,408 & 28,852 \\
\hline $\begin{array}{l}\text { (ATM) value } \\
\text { ( TZS billion) }\end{array}$ & 7,747 & 8,200 & 9,642 & 5,279 & 7,637 \\
\hline $\begin{array}{l}\text { (POS) value } \\
\text { (TZS billion) }\end{array}$ & 1,149 & 279 & 203 & 198 & 347 \\
\hline
\end{tabular}


According to Global Money Survey 2013, mobile money accounts outnumber bank accounts in nine African countries including Tanzania. Small business are using mobile money to pay supplies, receive customer payment, pay employees, saving and borrowing money and have more insurance service activities.

\subsection{Opportunities for financial innovations in Tanzania:}

Looking at the financial sector in Tanzania, despite of the various forms of reforms, the sectors is not yet developed enough to reach the highest levels. This is also true with the overall nature of innovations in the sector. Although we cannot deny the current growth, the sector still has yet to offer in order to improve the sector. Due to this, it is possible to argue the following:

Firstly, the market is wide open for parties interested in bringing up new innovations. Such innovations can come from both angels meaning private, governmental or individual, but the main point here should be to improve the financial innovations in a country. As presented in the introduction part, financial innovations does not benefit the customers only, even the financial institutions utilizing such innovations will benefit from it.

Secondly, both microeconomic and macroeconomic benefits flow from financial innovation have been observed in Tanzania financial market. At the micro-economic level, the current development of new financial instruments improves the capacity of financial intermediaries and end-users of financial markets to manage risks. Better management of risk, in turn, leads to the improved allocation of resources; in particular capital. At the macroeconomic level, financial innovation enlarges the menu / list of assets available to savers and borrowers. By designing savings vehicles / instruments, in a more attractive way and extending the reach of financial intermediation, saving is encouraged, and the utility of a given volume of savings to the holders of financial assets is enhanced. Similarly, on the borrowing side, the introduction of new borrowing instruments facilitates capital formation and perhaps improves its quality.

Thirdly, due to little number of financial institutions in general, there is still an assurance for market of innovated financial services. Basically, a point to note here is that, few financial institutions in a system means there is less competition for existing customers. Once one institution has innovated a particular service, there is still a chance for another institution to do the same.

Fourthly, there is still existence of a room for collaboration between these financial institution and colleges, especially telecommunication colleges.
Due to lack of such connection, utilization of such connection will help the financial institutions reducing overall costs they incur when working on innovating a particular service.

\subsection{Challenges hindering innovations in financial sectors}

Several challenges were discovered as hindering the growth of innovations in the financial sector in the country. Such challenges include:

a) Capital

Although in broader context capital cannot be seen as an obstacle, due to the expensiveness on the overall requirements of the materials and labor power needed to achieve or introduce innovations, capital is still a problem. Lack of capital hinders the growth of endeavors to undertake initiatives of developing particular innovations. In the country, this was also seen as the case. Due to lack of capital, majority of interested parties fail to achieve their intended innovations results leading to failure on the overall increase of innovations in the sectors. To solve this problem, there is a need for both financial institutions and other related institutions to set aside funds that will be specifically used to promote and steer up innovations in the sector.

b) Low level of technology

This is also another challenge that hinders the growth of innovations in the country. In this, the assumption is based on the current level of technology where the country technological level is low. Hence due to this, some of the innovations cannot be implemented as the existing technology will not be able to support them. Because of this, there is a need to fasten the speed of technological development in the country so as to be able to accommodate the new innovations that are brought about by various parties.

c) Lack of supporting policies

This was seen as a challenge to both the financial institutions and the other parties involved with financial sectors. In this, it was realized that there is a lack of policy support framework that is solely focused on supporting the innovation within the sector. Lack of policy framework affects the general direction of financial sector as there are no definite agreed objectives as to what should be achieved and when it should be. Due to this, there is a need for these financial sectors to have a policy framework that will focus on innovations alone either through motivating innovations, supporting the endeavors and provide the direction for innovations needed.

d) Risk creation

Individual financial incentives geared by growth of technology and financial engineering skills, can result in economic environment where new financial instruments, institutions and strategies outpace the existing market and regulatory systems. Such 
advancements have the potential to present challenges for both market participants and regulators. The transfer of risk to unknown counterparties could create concentration of risk exposures, within or outside the regulated financial sector. It is again uncertain that where exactly risk lies, and whether risk has been fully transferred. In such a situation investors may not fully understand the products in which they invest and the risks they are sharing on.

\section{CONCLUSION}

Financial innovation does have a dark side; it can have detrimental effects. There is evidence that financial innovations are sometimes undertaken to create complexity and exploit the purchaser (Allen, 2012). On overall, the respondents seemed "just happy" with the current rate of innovations within the sectors. But an in-depth analysis of their answers saw a desire of more advancement and innovations to carter their needs and simplify majority of the functions that are currently done the traditional way. Basically, during data collection it was realized that, most innovations activities in the sector were built on existing products and processes, involving reconfiguration and modification to existing functions and practices. The new entrance in financial market is clear threat to traditional financial services institutions. Their business models seem to react quickly to customer demands as they positioning themselves as alternatives to traditional financial services providers.

\section{RECOMMENDATIONS}

In general, each country has its own approach to fostering appropriate and useful financial innovation. The followings are general suggestions for Tanzania market looking to realize the benefits of financial innovation:

a) Tanzania has to introduce products that are straightforward and offer clear value-added. So, new financial products should be understood by regulators, by sellers and by prospective buyers.
Investors should be able to calculate the risks being undertaken without undue reliance on credit ratings agencies or other outside advisors.

b) The market should ensure that, the interests of the originators of loans and securitized assets are aligned with the interests of investors.

c) Regulation and supervision also must keep up with innovation. This requires both adequate resources to hire skilled professionals, together with political support to ensure that regulations and supervisory recommendations are taken seriously.

\section{REFERENCES}

[1] Allen, F (2012) Trends in Financial Innovation and their Welfare Impact: an Overview, European Financial Management, Vol. 18, No. 4, 2012, 493-514

[2] Blach, J (2011) Financial Innovations and their role in the Modern Financial System Identification and Systematization of the Problem, Financial Internet Quarterly „e-Finance” 2011, vol. 7, nr 3

[3] Damanpour, F. and Schneider, M. (2006), "Phases of the adoption of innovation in organizations: effects of environment, organization and top managers", British Journal of Management, Vol. 17 No. 3, pp. 215-36.

[4] Diyamett (2010) Inter-organizational linkages and firms' innovativeness in least developed countries. The Case of Metal Working and Engineering Sector in Tanzania. PhD (Development Studies) Thesis University of Dar es Salaam

[5] Fagerberg, J. and Verpagen B. (2004), "Innovation, Growth and Economic Development: Why Some Countries Succeed and Others Don't", Working Paper 02/04, University of Oslo

[6] Frame, W. Scott and L. J. White, (2002). Empirical Studies of Financial Innovation: Lots of Talk, Little Action? (Working Paper 2002-12). Atlanta, GA, USA: Federal Reserve Bank of Atlanta.

[7] Kortum, S. and Lerner, J., 'Assessing the contribution of venture capital to innovation', Rand Journal of Economics, Vol. 31, 2000, pp. 674-92.

[8] Lerner, J. and Tufano, P., 'The consequences of financial innovation: a counterfactual research agenda', Working Paper (Harvard Business School, 2010).

[9] Michalopoulos, S., L. Leaven, R. Levine, (2009). Financial Innovation and Endogenous Growth. National Bureau of Economic Research, Working Paper 15356, Cambridge, September, p. 1-33. 